\title{
Shelf Life Evaluation of Trichoderma harzianum on Different Organic Urban Waste
}

\author{
Binit Kumar $^{1 *}$, Chanchila Kumar ${ }^{1}$, Manish Kumar ${ }^{1}$ and V.K. Singh ${ }^{2}$ \\ ${ }^{1}$ KVK, Koderma, ICAR-NRRI-CRURRS, Jharkhand, India \\ ${ }^{2}$ Principal Scientist, IISR, Lucknow, Uttar Pradesh, India \\ *Corresponding author
}

A B S T R A C T

\begin{tabular}{|c|}
\hline Keywords \\
\hline $\begin{array}{l}\text { Trichoderma } \\
\text { harzianum, Urban } \\
\text { waste and Self life }\end{array}$ \\
\hline Article Info \\
\hline $\begin{array}{l}\text { Accepted: } \\
18 \text { April } 2018 \\
\text { Available Online: } \\
\text { 10 May } 2018\end{array}$ \\
\hline
\end{tabular}

Keywords

Trichoderma harzianum, Urban waste and Self life

Article Info

18 April 2018

Available On May 2018

\section{Introduction}

Trichoderma harzianum is one of the common fungal bio-agent belongs to sub-division deuteromycotina and worldwide used for sustainable management of various foliar, seed borne and soil borne pathogens due to antagonistic nature of the fungi. The members of genus Trichoderma are free-living, opportunist, a virulent, symbiotic fungus that are common in soil and root ecosystem (Harman et al., 2004). Antifungal metabolites of Trichoderma have been grouped by Ghisalberti and Sivasithamparam (1991). Trichoderma spp. is known to produce mycolytic enzymes such as $\beta-1,3$, glucanasa, $\beta-1,4$ endo-glucanase, chitinase and protease. These enzymes play an important role in the degradation of chitin which is the structural component of the target pathogens and herbivorous insects and consequent mycoparasitism (Harman et al., 1993). Trichoderma has gained maximum attention as bio-control agent due to the fact that it is effective against a large number of soil-borne plant pathogenic fungi, suppressive effects on some root nematodes without adversely affecting beneficial microbes like Rhizobium and capable of promoting growth of certain crops. Bio-control technologies have gained 
momentum in disease control of crop plants in recent times as these technologies not only minimize or replace the usage of harmful chemical pesticides but also found to be cheaper control of some of the diseases like, foot rots, root rots, damping off, collar rots, wilts and many soil borne diseases. Mass production of Trichoderma required to find out suitable media on large amount of Trichoderma biomass is required therefore, the first step for the mass production of any bio-control agent is to identify the suitable substrates, which should be comparatively cheap, stable and easily available within a short period of time. The type and form of substrate i.e. broth and solid may also vary according to the specific purpose for which bio-control agent biomass is required. In India, talc based formulations of $T$. viride was developed at Tamil Nadu Agricultural University, Coimbatore for seed treatment of pulse crops and rice (Jeyarajan et al., 1994).

\section{Materials and Methods}

Standard pure culture of Trichoderma was brought from Department of Plant Pathology, Birsa Agriculture University, Kanke, Ranchi (Jharkhand). It has a shorter life period, so periodical sub culturing was done after fifteen days. The experiment was incepted at Krishi Vigyan Kendra, Koderma (Jharkhand). Sterilization of glass ware was done in Autoclave (at $121^{\circ} \mathrm{C}$ for $30 \mathrm{~min}$ ). All the selected substrate urban waste materials i.e. Sugarcane baggage, Peeled potato, Cow dung, Waste tea leaf and Farm Yard Manures have been collected from local area and after washing with clean tap running water substrate were placed in shade for 72 hours. The moisture level of each substrate was adjusted to $60 \%$, using oven dry method by adding known quantity of water considering the initial moisture content. After drying in shaded place first step of sanitization of substrate was done with Formaldehyde @3\%. Then the materials were filled in conical flask with the weight of $100 \mathrm{~g}$ of substrate in each flask. After filling of conical flask the substrate were autoclaved for 30 minutes at $121^{\circ} \mathrm{C}$. The experiment was designed according to CRD; each treatment combination was replicated five times. Initial multiplication of Trichoderma sp. was done on Potato Dextrose Agar medium and inoculation on substrate was done in broth. The all replicates of experiment were left for 7 days under dark shade on $25^{\circ} \mathrm{C}$. After that an aliquot of $10 \mathrm{ml}$ of distilled sterile water (DSW) was added to each flask and the mycelium was scraped with a spatula until the culture surface was free from mycelia and the suspension was collected in a $100 \mathrm{ml}$ conical flask (Nampoothiri et al., 2004). Serial dilution technique was used for reducing conidial strength in suspension. The number of conidia was determined by a Haemocytometer (Pandey et al., 2001) and calculated as conidia/g of substrate. One gram of conidial substrates was mixed with $9 \mathrm{ml}$ of distilled and sterilized water. The mixtures of conidial substrates were filtered through three layers of cheese cloth. One $\mathrm{ml}$ of collected suspension of Trichoderma sp. was poured on PDA containing Petri Plates under Laminar Air Flow chamber and leave for five days at $25^{\circ} \mathrm{C}$ room temperature (Rahman et. al., 2011). After five days of inoculation circular white patches of mycelium was observed on PDA medium. Colony counter meter was used for counting number of spores per $\mathrm{ml}$ of suspension in each replication of substrate. Different agro industrial wastes were evaluated for maximum conidia production of Trichoderma under solid state fermentation (Cavalcante et al., 2008). The calculation of conidial spore on substrate was done periodically after seven days of interval.

\section{Results and Discussion}

Among the substrates tested, waste tea leaf produced maximum number of conidia 156.3 in $10^{-5}$ dilution point moreover maximum days 
survival $18.5 @ 30^{\circ} \mathrm{C}$ have been recorded which was followed by Farm Yard Manures 120.1 (16.3 days), Cow dung 98.2 (16.5 days), Peeled potato 82.8 (15.6 days) and Sugarcane Baggage Solid 46.1 (12.3 days). Moreover the maximum radial growth and minimum days took place to whole mycelium run observed with waste tea leaf (9.2 days) followed by cow dung (12.5), Sugarcane Baggage (14.2), Farm Yard Manures (15.6 days) and peeled potato (18.3 days) (Fig. 1 and 2; Table 1 and 2).

Table.1 The periodical conidia yield of Trichoderma harzianum using different

\begin{tabular}{|c|c|c|c|}
\hline \multirow[t]{2}{*}{ Substrate Type and weight } & \multicolumn{3}{|c|}{ Development of Spores periodically @ $10^{-5}$} \\
\hline & $7^{\text {th }}$ day & $15^{\text {th }}$ day & $21^{\text {st }}$ days \\
\hline Sugarcane Baggage Solid $(100 \mathrm{~g}) \times 50 \mathrm{ml}$ & 10.2 & 23.7 & 46.1 \\
\hline Peeled Potato Solid $(100 \mathrm{~g}) \times 50 \mathrm{ml}$ & 21.3 & 45.8 & 82.8 \\
\hline Waste Tea Leaf Solid $(100 \mathrm{~g}) \times 50 \mathrm{ml}$ & 36.8 & 72.1 & 156.3 \\
\hline Cow Dung Solid $(100 \mathrm{~g}) \times 50 \mathrm{ml}$ & 28.7 & 46.9 & 98.2 \\
\hline Farm Yard Manures Solid $(100 \mathrm{~g}) \times 50 \mathrm{ml}$ & 32.4 & 69.4 & 120.1 \\
\hline
\end{tabular}

Table. 2 The periodical mycelia growth, number of spore/conidia yield and self life of Trichoderma harzianum using different

\begin{tabular}{|l|c|c|c|}
\hline \multicolumn{1}{|c|}{ Substrate Type and weight } & Mycelia growth & Spore $\mathbf{( 1 0}^{-\mathbf{5}}$ ) & $\begin{array}{c}\text { Self life } \\
\text { Days@ 30 }\end{array}$ \\
\hline Sugarcane Baggage Solid $\mathbf{( 1 0 0 g )} \times \mathbf{5 0} \mathbf{~ m l}$ & 14.2 & 46.1 & 12.3 \\
\hline Peeled Potato Solid $(\mathbf{1 0 0 g}) \times \mathbf{5 0} \mathbf{~ m l}$ & 18.3 & 82.8 & 15.6 \\
\hline Waste Tea Leaf Solid $(\mathbf{1 0 0 g}) \times \mathbf{5 0} \mathbf{~ m l}$ & 9.2 & 156.3 & 18.5 \\
\hline Cow Dung Solid $(\mathbf{1 0 0 g}) \times \mathbf{5 0} \mathbf{~ m l}$ & 12.5 & 98.2 & 16.5 \\
\hline Farm Yard Manures Solid $(\mathbf{1 0 0 g}) \times \mathbf{5 0} \mathbf{~ m l}$ & 15.6 & 120.1 & 16.3 \\
\hline
\end{tabular}

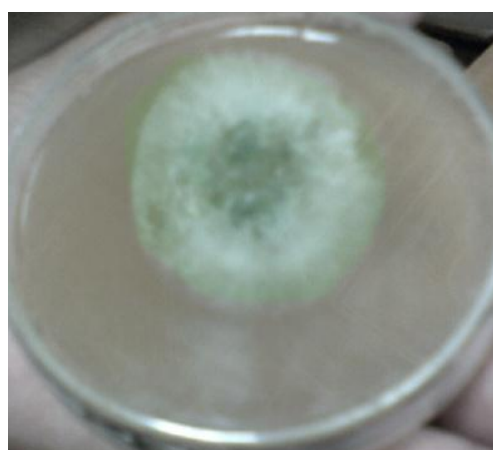

Fig.1 Colony development on PDA

The most probable reason according to limited information available regarding the usage of different urban waste materials for mass multiplication of Trichoderma

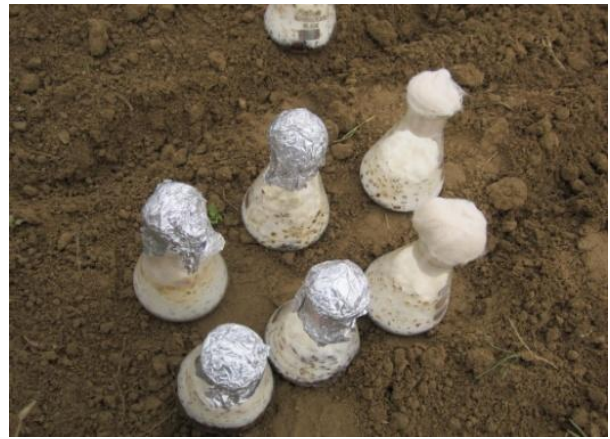

Fig.2 Mass multiplication of Trichoderma

harzianum may have been the $\mathrm{C} / \mathrm{N}$ ratio, availability of micro and macro nutrients, growth region, structure of species and physical condition of substrate i.e. bulk 
density, porosity, water holding capacity accelerate the development of spore (Gupta et al., 1997 and Irshad et. al., 2011). The other microbiologist have been also support the possible reasons for the waste tea leaf substrate may be useful for mass multiplication of Trichoderma sp. on low cost substrate.

\section{References}

Cavalcante R S, Lima HLS, Pinto GAS (2008). Effect of Moisture on Trichoderma Conidia Production on Corn and Wheat Bran by Solid State Fermentation. Food Bioprocess Tech 1: 100-104.

Ghisalberti, E. L. and K, Sivasithamparam (1991). Antifungal antibiotics produced by Trichoderma spp. Soil biology and Biochemistry, 23: 1011-1020.

Gupta R, Saxena RK, Goel S (1997). Photoinduced sporulation in Trichoderma harzianum an experimental approach to primary events. World Journal of Microbiology and Biotechnology 13: 249-250.

Harman, G. E., X. Jin, T.E. stasz, G. Peruzzaoil, A. C. Leopoid and A.G. Taylor (1993). Production of conidial biomass of Trichoderma harzianum for biological control. Biological control, 1: 23-38

Harman GE, Howell CR, Viterbo A, Chet I,
Lorito M (2004). Trichoderma species: opportunistic, avirulent plant symbionts. Nature reviews of Microbiology. 2: 43 56.

Irshad M, Anwar Z, Kamboh NA (2011). Production of Xylanase by Humicola lanuginosa in Solid State Culture by Screening Lignocellulosic Substrates. Middle-East Journal of Scientific research (MEJSR) 8: 364-370.

Jeyarajan R, Ramakrishnan G, Dinakaran D, Sridar R (1994). Development of products of Trichoderma viride and Bacillus subtilis for biocontrol of root rot diseases, 25-36. In Biotechnology in India (Ed Dwivedi B.K.) Bioved Research Society, Allahabad.

Nampoothiri K M, Baiju T V, Sandhya C (2004). Process optimization for antifungal chitinase production by Trichoderma harzianum. Process Biochemistry. 39: 1583-1590.

Pandey A, Soccol CR, Rodriguez-Leon J A (2001). Solid state fermentation in biotechnology. New Delhi: Asia Tech Inc, 237.

Rahman A, Begum MF, Rahman M (2011). Isolation and identification of Trichoderma species from different habitats and their use for bioconversion of solid waste. Turk Journal of Biology 35: 183-194.

\section{How to cite this article:}

Binit Kumar, Chanchila Kumar, Manish Kumar and Singh, V.K. 2018. Shelf Life Evaluation of Trichoderma harzianum on Different Organic Urban Waste. Int.J.Curr.Microbiol.App.Sci. 7(05): 2351-2354. doi: https://doi.org/10.20546/ijcmas.2018.705.270 